\title{
INOVASI MANAJEMEN PENGAJARAN DALAM PENINGKATAN PRESTASI SISWA KELAS X SMA IT SAMAWA CENDEKIAN KABUPATEN SUMBAWA TAHUN 2020
}

\author{
Muslim 1, Dr. Harjito ${ }^{2^{\star}}$ \\ ${ }^{1}$ Mahasiswa Pascasarjana Manajemen Inovasi Universitas Teknologi Sumbawa \\ ${ }^{*}$ Dosen Pascasarjana Manajemen Inovasi Universitas Teknoogi Sumbawa \\ *Corresponding Author email: harjito@uts.ac.id
}

\begin{abstract}
Diterima :

Bulan September 2020

Diterbitkan : Bulan Oktober 2020

Keyword : Teaching innovation, Chauvenet Criterion, Students achievement

Penelitian ini didasarkan pada kondisi kerentanan penurunan prestasi siswa pada tingkat Sekolah Menengah Atas akibat perubahan kurikulum selama satu dekade terakhir. Peranan lebih dari pendidik (Guru) sangat dibutuhkan terutama pada segi Inovasi pengajarannya. Sehingga perlu dilakukan perumusan tingkat efektifitas inovasi manajemen pengajaran dalam meningkatkan prestasi siswa SMA di wilayah Sumbawa tahun 2020. Metode penelitian yang digunakan adalah jenis kualitatif yang diterapkan pada SMA Islam Terpadu Samawa Cendekia tahun ajaran Genap 2019. Adapun informan dalam penelitian ini yakni Wakil Kepala Sekolah bidang kesiswaan, Guru dan juga siswa. Teknik pengumpulan data melaui metode wawancara, observasi dan dokumentasi. Analisa data menggunakan metode interaktif, penyajian data, reduksi data dengan Chauvenet Criterion dan digeneralisasi untuk kesimpulan. Hasil penelitian terkait efektifitas inovasi manajemen pengajaran dalam peningkatan prestasi siswa yaitu inovasi pengajaran bukan pada wujud fisik melainkan juga yang non fisik oleh guru. Perencanaan program dalam pengembangan potensi guru untuk menciptakan inovasi dalam pembelajaran. Manajemen pengaturan kelembagaan pada struktur organisasi, pengelolaan, pengembangan potensi guru secara inovatif melalui kegiatan workshop, diklat, pelatihan inovasi dalam pengajaran, sehingga berkorelasi positif terhadap prestasi siswa. Pengawasan manajemen inovasi dilakukan oleh Kepala Sekolah terhadap Guru serta supervisi oleh Pengawas dari Dinas Pendidikan Kabupaten yang dilakukan rutin setiap bulannya.
\end{abstract}

\section{PENDAHULUAN}

Dalam sistem pendidikan nasional, pelaksanaan inovasi pendidikan melalui proses dari atas ke bawah. Dalam inovasi menejemen pengajaran proses penyebaran inovasi dapat dilakukan melalui pelatihan, pengumuman, kursus, bengkel, dan seminar. Inovasi menejemen pengajaran berorientasi kepada life instructiona lsebagai wujud terciptanya Proses Belajar Mengajar (PBM) berkualitas. PBM berkualitas menunjukkan kegiatan seperti; dinamis, interaktif, daya serap mudah, siswa terpicu untuk berpikir, sikap perhatian antusias menimbulkan minat, rasa ingin melakukan, kemauan mencoba dalam praktik, kontekstual dengan kenyataan, terpatri nilai-nilai luhur, budaya, pemahaman sinergi dengan Bhinneka Tunggal Ika. Penguatan ajaran islam dan pembentukan karakter siswa meraih prestasi (A. Rusdiana, 2002).

Proses pembangunan dari bawah dapat dimulai dari tingkat daerah. Membangun pendidikan di Nusa Tenggara Barat (NTB) akan lebih baik jika berbasis dari permasalahan-permasalahan lokal, untuk kemudian dicarikan jalan keluar yang diistilahkan sebagai solusi lokal. Salah satu cara inovasi yang paling efektif yaitu dengan menampilkan kemasan yang berbeda dari biasanya. Pelaksanaan program-program rintisan Inovasi mendorong para tenaga pendidik menemukan praktik-praktik pengajaran yang dapat meningkatkan kemampuan literasi dan numerasi anak didik serta dalam meningkatkan kualitas pembelajaran peserta didik berkualitas di Nusa Tengara Barat (Satria Z Rasyid 2018).

Salah satu sekolah di NTB yang perlu melaksanakan manajemen inovasi pengajaran adalah SMA IT Samawa Cendekia. Inovasi menejemen pengajaran merupakan proses menuju mutu mengajar guru, kelancaran layanan belajar mengajar, umpan balik yang diterima siswa, kepuasan siswa terhadap layanan mengajar, pengelolaan layanan siswa serta sarana dan prasarana sekolah (Djam'an Satori, 2000). Demikian halnya dengan peningkatan prestasi siswa mencapai mutu unggul perlu dilakukan oleh guru dalam merencanakan, pengorganisasian, pengarahan tindakan, dan pengendalian kualitas siswa di SMA Islam Terpadu Samawa Cendekia. Terdapat beberapa gejala mendasar, diantaranya; (a) 
siswa tidak dipahamkan visi misi Sekolah Islam Terpadu padahal belajar di lingkungan Yayasan Samawa Cendekia, (b) faktor internal yaitu dari dalam diri siswa sendiri, (c) faktor eksternal yakni faktor dari luar diri siswa, lingkungan keluarga yang tidak harmonis, rendahnya hubungan orang tua dan anak, kurangnya disiplin yang diterapkan orang tua pada anaknya dan tidak sedikit pola asuh secara single parent. Kondisi inilah yang memungkinkan kompensasi yang cenderung ke arah negatif seperti presensi, keterlambatan, dan berbagai bentuk pelanggaran yang dilakukan oleh siswa sehingga prestasi akademik siswa rendah.

Prestasi belajar yang dicapai siswa di SMA IT Samawa Cendekia tentunya memiliki tingkatan yang berbeda-beda, ada yang tinggi sedang dan rendah. Tujuan belajar tercapai terlihat dari hasil prestasi yang tinggi dari kegiatan belajar siswa sedangkan jika prestasi rendah maka menunjukkan ketidakberhasilan mencapai tujuan pembelajaran. Hal tersebut didukung oleh pendapat Djamarah (2006:128) apabila materi pengajaran yang diajarkan kurang dari 65\% dikuasai siswa maka prestasi siswa pada masing-masing mata pelajaran tersebut belum tercapai.

David McClelland seorang ahli psikologi sosial yang terkenal dengan pemikirannya mengenai motivasi berprestasi mengemukakan bahwa dorongan atau motivasi berprestasi merupakan sesuatu yang ada dan dibawa sejak lahir. Namun dalam banyak hal, motivasi berprestasi merupakan suatu hal yang ditumbuhkan atau dikembangkan, hasil dari mempelajari melalui interaksi lingkungan (Sobur, 2003). Motivasi berprestasi juga dapat diartikan sebagai suatu keingian yang berkaitan dengan pencapaian standar internal yang optimal. Seseorang yang mempunyai motivasi berprestasi tinggi mempunyai ketahanan diri, keberanian mengambil resiko dan akan bertanggung jawab (Iksan, 2012:11).

Selama ini kondisi pembelajaran di SMA Islam Terpadu Samawa Cendekia masih memperoleh hasil yang tidak maksimal. Ini terlihat pada keberhasilan belajar siswa dalam mencapai tujuan pelajaran. Prestasi belajar siswa mayoritas masih di bawah KKM (Kriteria Ketuntasan Minimal) yang telah ditentukan sekolah Berikut ini data prestasi belajar kelas X di SMA Islam Terpadu Samawa Cendekia tahun pelajaran 2019/2020.

Tabel 1.1 Prestasi belajar siswa kelas X di SMA Islam Terpadu Samawa Cendekia tahun pelajaran 2019/2020

\begin{tabular}{|l|l|l|l|}
\hline $\begin{array}{l}\text { Rentang } \\
\text { Nilai }\end{array}$ & Frekuensi & Perentase & Keterangan \\
\hline$>70$ & 15 & 68,2 & Tuntas \\
$<70$ & 7 & 31,2 & $\begin{array}{l}\text { Belum } \\
\text { Tuntas }\end{array}$ \\
\hline & 22 & 100 & \\
\hline
\end{tabular}

Sumber: SMA IT Samawa Cendekia Tahun Pelajaran 2019/2020

Kriteria yang dijadikan pedoman dalam menentukan ketuntasan belajar siswa (KKM) di SMA IT Samawa Cendekia adalah 70. Jika siswa memperoleh nilai minimal 70 maka siswa tersebut dianggap tuntas dan sebaliknya jika siswa memperoleh nilai < 70, maka siswa tersebut dianggap belum tuntas. Pada tabel di atas, dapat dilihat bahwa persebaran nilai siswa tidakmerata, yaitu terdapat 13 siswa atau 57,2\% yang mendapat nilai dibawah 70 atau dinyatakan belum tuntas, sedangkan sebanyak 18 siswa atau 42,8 \%siswa yang dinyatakan tuntas atau mendapat nilai diatas 70 pada semua mata pelajaran. Karena mengingat adanya perbedaan dari setiap individu baik motivasi, minat, aktivitas, cita-cita, lingkungan keluarga, dan lain-lain yang dimiliki setiap siswa akan mengakibatkan prestasi belajar yang diperoleh siswa berbeda-beda pula. Terjadinya perbedaan ini tentu saja dipengaruhi oleh berbagai faktor. Faktor-faktor tersebut diantaranya media pembelajaran yang digunakan, motivasi, dan aktivitas belajar siswa.

Untuk mengatasi masalah tersebut dibutuhkan inovasi manajemen pengajaran yang diharapkan akan terjadi peningkatan prestasi siswa SMA Islam Terpadu Samawa Cendekia khususnya dan SMA di Kabupaten Sumbawa pada umumnya. Sehingga mendorong untuk dilakukan kajian lanjutan melalui penelitian berjudul "Inovasi manajemen pengajaran dalam peningkatan prestasi siswa SMA di Kabupaten Sumbawa" dengan studi kasus pada SMA IT Samawa Cendekia. Adapun tujuan penelitian ini adalah untuk mengetahui pengaruh inovasi manajemen pengajaran serta seberapa efektif pengaruh inovasi pengajaran terhadap peningkatan prestasi siswa.

\section{LANDASAN TEORI}

\section{Inovasi Manejemen Pengajaran}

Begitu Kita tahu bahwa setiap generasi memiliki keunikannya masing-masing dalam menciptakan sesuatu yang baru. Setiap generasi bisa membuat "gebrakan baru" tersendiri yang dapat memukau para generasi lain. Tidak hanya sebuah gebrakan baru, namun hal tersebut bisa digunakan oleh banyak orang. Misalnya, generasi muda millennial membuat suatu kosa kata gaul baru dan nantinya kosa kata tersebut dijadikan suatu benda yang inovatif oleh seseorang. Sampai akhirnya, benda tersebut pun bisa memudahkan kegiatan manusia dan bisa dikategorikan sebagai inovasi baru.

Di zaman modern seperti sekarang ini, contoh inovasi adalah suatu kosakata menarik yang dibuat terkenal oleh para millennial yaitu, selfie (berfoto sendiri). Kata selfie ini kemudian menjadi 
sangat booming di semua generasi. Sampai pada akhirnya, orang-orang yang inovatif membuat suatu benda yang dinamakan tongsis, yang sangat bermanfaat bagi orang-orang yang suka melakukan selfie. Ada bermacam-macam inovasi dalam kehidupan kita, begitu juga manfaat inovasi yang diberikan kepada kehidupan manusia.

Jika Inovasi adalah keabadian, Lantas bagaimana dengan Pengertian Inovasi? Inovasi menurut Lilian (2018:10) adalah suatu contoh dimana suatu kreativitas, daya cipta dan inisiatif kuat dapat menghasilkan sesuatu yang secara materi jauh lebih baik daripada penemuan-penemuan sebelumnya. Jadi, salah satu tujuan inovasi adalah menciptakan kemudahan baru untuk kehidupan manusia melalui penemuan atau perkembangan baru dari ide-ide inovatif yang berhasil diwujudkan dengan baik. Suatu inovasi juga erat kaitannya dengan inovasi produk. Inovasi produk adalah suatu penciptaan baru yang mengandung beberapa unsur di seperti Teknologi baru, layanan dan solusi baru, pengalaman baru, Proses dan metode baru dan lainlain.

Dengan demikian, inovasi dapat dimaknai sebagai suatu ide, produk, informasi teknologi, kelembagaan, perilaku, nilai-nilai, atau praktekpraktek baru yang belum banyak diketahui, dan digunakan/diterapkan oleh sebagian besar warga masyarakat yang dapat mendorong terjadinya perubahan yang lebih baik.

Secara umum, pengertian manajemen merupakan suatu seni dalam ilmu dan pengorganisasian seperti menyusun perencanaan, membangun organisasi dan pengorganisasiannya, pergerakan, serta pengendalian atau pengawasan. Bisa juga diartikan bahwa manajemen merupakan suatu ilmu pengetahuan yang sistematis agar dapat memahami mengapa dan bagaimana manusia saling bekerja sama agar dapat menghasilkan sesuatu yang bermanfaat bagi orang lain maupun golongan tertentu dan masyarakat luas.

Secara etimologis, pengertian manajemen merupakan seni untuk melaksanakan dan mengatur. Manajemen ini juga dilihat sebagai ilmu yang mengajarkan proses mendapatkan tujuan dalam organisasi, sebagai usaha bersama dengan beberapa orang dalam organisasi tersebut sehingga ada orang yang merumuskan dan melaksanakan tindakan manajemen yang disebut dengan manajer.Pada dasarnya, fungsi manajemen dibagi menjadi empat, antara lain: Perencanaan (planning), Pengorganisasian (organizing). Pengarahan (actuating) dan Evaluasi (controlling).

Pengajaran Adalah - Menurut Para Ahli, Makalah Fungsi \& Tujuan - Pengajaran sering diartikan sama dengan kegiatan mengajar, dalam arti yang lain pengajar diartikan telah terjadinya interaksi belajar mengajar antara komponenkomponen pengajaran khususnya antara guru dan siswa antara siswa dengan siswa dan antara guru dan siswa dengan komponen-komponen pengajaran lainnya. Pengajaran juga sering diartikan sama dengan kegiatan pendidikan.

Yang dalam pengertian yang lain pengajaran ialah terjadinya dua aktivitas yang berbeda antara pihak guru dengan pihak siswa. Aktivitas guru ialah mengajar yang berperan mengupayakan jalinan komunikasi atau interaksi yang harmonis antara kegiatan belajar yang dilakukan oleh siswa.

Ukuran keberhasilan pengajaran ialah tercapainya komunikasi yang harmonis guru dengan siswa. indikator keberhasilan pengajaran lainnya ialah terjadinya perubahan tingkah laku para diri siswa serta tertanamnya dalam diri siswa tentang kebutuhan akan belajar serta manfaat belajar.

Pengajaran tidaklah lain salah satu bagian dari pendidikan dengan cara memberikan ilmu pengetahuan serta kecakapan dalam mendidik anak didiknya. Jika pengajar ini kurang dilakukan disekolah maka dapat diduga hasil pendidikan tidaka akan sempurna atau berhasil dalam mengembangkan anak didik secara utuh.

\section{Peningkatan Prestasi Akademik}

Pengertian peningkatan secara epistemologi adalah menaikkan derajat taraf dan sebagainya mempertinggi memperhebat produksi dan sebagainya proses cara perbuatan meningkatkan usaha kegiatan dan sebgainya kini telah diadakan di bidang pendidikan menteri kesehatan menentukan perlunya pengawasan terhadap usaha perdagangan eceran obat sedangkan Kamus Besar Bahasa Indonesia menyatakan Mutu adalah ukuran baik buruk suatu benda taraf atau derajat kepanda, kecerdasan, dan sebagainya kualitas. Sebelum membahas tentang mutu pendidikan terlebih dahulu akan dibahas tentang mutu dan pendidikan banyak ahli yang mengemukakan tentang mutu seperti yang dikemukakan oleh Edward Sallis mutu adalah sebuah filsosofis dan metodologis yang membantu institusi untuk merencanakan perubahan dan mengatur agenda dalam menghadapi tekanantekanan eksternal yang berlebihan. Sumayang menyatakan quality, mutu adalah tingkat dimana rancangan spesifikasi sebuah produk barang dan jasa sesuai dengan fungsi dan penggunannya Kegiatan sehingga akan mengalami perubahan menjadi lebih baik. Menurut Adi (2001),dalam kamus bahasanya istilah peningkatan berasal dari kata tingkat yang berarti berlapis-lapis darisesuatu yang tersususun sedemikian rupa, sehingga membentuk suatu susunan yang ideal, sedangkan peningkatan adalah kemajuan dari seseorang dari tidaktahu menjadi tahu, dari tidak bisa menjadi bisa.Peningkatan adalah proses, cara, perbuatan untuk menaikkan sesuatu atau usaha kegiatan untuk 
memajukan sesuatu ke suatu arah yang lebih baik lagi daripada sebelumnya.Berdasarkan uraian di atas dapat disimpulkan bahwa peningkatan adalah suatu upaya yang dilakukan oleh pembelajar (guru)untuk membantu pelajar (siswa) dalam meningkatkan proses pembelajaran sehingga dapat lebih mudah mempelajarinya. Pembelajaran dikatakan meningkat apabila adanya suatu perubahan dalam proses pembelajaran, hasil pembelajaran dan kualitas pembelajaran mengalami perubahan secara berkualitas.

\section{METODE PENELITIAN}

\section{Pendekatan Penelitian}

Dalam penelitian ini menggunakan pendekatan deskriptif kualitatif. Pendekatan penelitian secara kualitatif dilakukan berkenaan dengan data-data yang dikumpulkan berupa katakata, kalimat bukan angka, dan mengkaji berbagai fenomena. Pada penelitian kualitatif ini, peneliti sebagai instrumen pertama dan utama dalam pengumpulan data.

Dengan demikian, peneliti melakukan pengumpulan data dengan pengamatan, wawancara, dan dokumen secara langsung. Penelitian kualitatif memiliki kemungkinan besar pengumpulan data dilakukan dengan observasi dan wawancara. Dalam hal ini, data memungkinkan untuk dilakukan pencatatan dan perekaman, baik yang diperoleh dengan pengamatan maupun wawancara. Adapun teknik pengumpulan data dan informasi secara objektif dalam penelitian ini dilakukan dengan wawancara dan dokumentasi yang menghasilkan data dan informasi yang soheh, terkini dan relevan dari fokus penelitian yang berkaitan dengan inovasi menejemen pengajaran dalam peningkatan prestasi siswa SMA di Kabupaten Sumbawa.

\section{Subjek dan informan}

Subjek penelitian ini ialah guru Kelas X melakukan inovasi menejemen pengajaran dalam peningkatan prestasi siswa Kelas X di Sekolah Menengah Atas Islam Terpadu (SMAIT) Samawa Cendekia Sumbawa Kabupaten Sumbawa. Adapun informan-informan dalam penelitian iniyakni Wakil kepala sekolah bidang kesiswaan, guru dan juga siswa

\section{Waktu dan Tempat Penelitian}

Penelitian ini dilaksanakan di SMAIT

Samawa Cendekia Sumbawa Kabupaten Sumbawa.Penelitian dilaksanakan 2 bulan terhitung bulan Juni - Juli 2020.

\begin{tabular}{|c|l|c|c|c|c|c|}
\hline No & \multicolumn{1}{|c|}{ Kegiatan } & \multicolumn{5}{|c|}{ Tahun 2020 } \\
\cline { 3 - 6 } & & Apr & Mei & Jun & Jul & Agu \\
\hline 1 & $\begin{array}{l}\text { Tahap Persiapan } \\
\text { Penelitian }\end{array}$ & & & & & \\
\hline
\end{tabular}

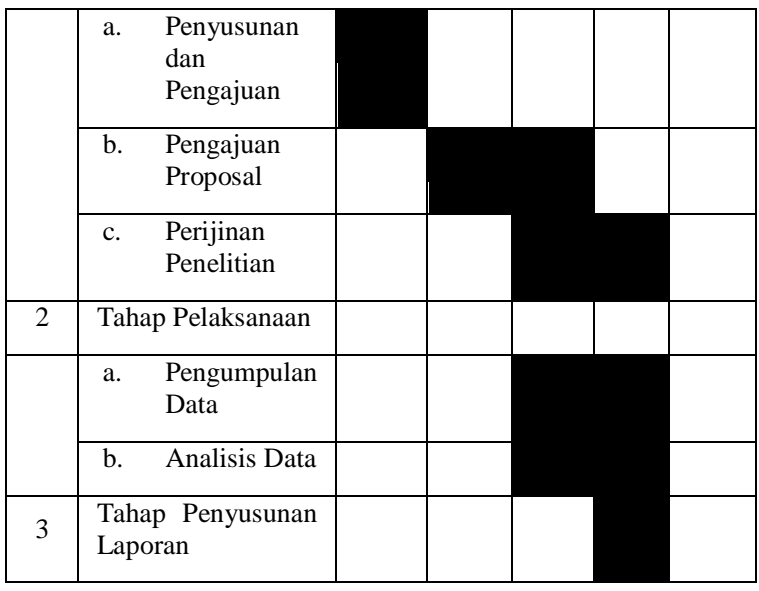

Untuk memperoleh data yang dibutuhkan, digunakan tiga teknik pengumpulan data yaitu:

\section{a. Observasi/Pengamatan}

Bahwasanya metode pengamatan digunakan untuk mengumpulkan data sebagai data awal untuk ditindak lanjuti dengan metode lain. Data yang dikumpulkan dengan metode pengamatan merupakan awal memperoleh informasi ilmiah. Sebagai metode ilmiah observasi biasadiartikan sebagai pengamatan dan pencatatan dengan sistematik fenomena-fenomena yang diselidiki

\section{b. Wawancara/Interview}

Wawancara ini dilakukan untuk menggali data tentang inovasi menejemen pengajaran dalam peningkatan prestasi siswa. Wawancara ini akan di tujukan kepada wakil kepala sekolah bagian kesiswaan. Wawancara merupakan teknik pengumpulan data yang sesuai berdasarkan laporan verbal di mana pada wawancara ini terdapat dialog yang dilakukan oleh interviewer (pewawancara) untuk memperoleh informasi dari interview (orang yang diwawancarai).

\section{c. Dokumentasi}

Dokumentasi ini digunakan untuk memperoleh data dari responden dengan melihat dokumen yang benar-benar asli, melalui dokumen tersebut peneliti menggambil data tentang guru dan siswa. Dalam penelitian ini, metode pengumpulan data menggunakan dokumen, tentang inovasi menejemen pengajaran dalam peningkatan prestasi siswa kelas x di Sekola Menengah Atas Islam Terpadu Samawa Cendekia (SMA IT SC) Kabupaten Sumbawa. Data dokumen merupakan pendukung autentik sebagai penyerta dalam proses pengelolaan siswa.

\section{Pemeriksaan Keabsahan Data}

Keabsahan data dalam penelitian ini dilakukan melalui teknik triangulasi dan konfirmasi dengan ahli. Triangulasi pada penelitian ini, peneliti gunakan sebagai pemeriksaan melalui sumber 
lainnya. Dalam pelaksanaannya peneliti akan melakukan pengecekan data yang berasal dari wawancara. Lebih jauh lagi, hasil wawancara tersebut kemudian peneliti cek dengan hasil pengamatan yang peneliti lakukan selama masa penelitian untuk mengetahui inovasi manajemen pengajaran dalam peningkatan prestasi siswa kelas X SMA Islam Terpadu Samawa Cendekia. Selain teknik triangulasi uji keabsahan data juga menggunakan teknik konfirmasi dengan ahli yang dalam penelitian ini dilakukan melalui diskusi dengan wakasek kesiswaan.

\section{Teknik Analisis Data}

Dalam penelitian kualitatif, analisis data dilaksanakan sebelum peneliti terjun ke lapangan, selama peneliti mengadakan penelitian di lapangan, sampai dengan pelaporan hasil penelitian. Analisis data dimulai sejak peneliti menentukan fokus penelitian sampai dengan pembuatan laporan penelitian selesai. Jadi teknik analisis data dilaksanakan sejak merencanakan penelitian sampai penelitian selesai.

\section{HASIL DAN PEMBAHASAN}

\section{Perencanaan (Planning)}

Berkenaan dengan kenyataan adanya gap antara ide-ide strategi dan pendekatan dalam inovasi pengajaran serta implementasinya di SMA Islam Terpadu Samawa Cendekia. Untuk itu, inovasi menejemen pengajaran perlu memperhatikan; rancangan, pelaksanaanya, pemantauan dan evaluasinya. Jika selama ini hanya rutinitas dengan RPP yang dibuat masih terkesan statis pasif tidak menggerakkan potensi siswa, maka sangat perlu melakukan inovasi dalam hal menejemen pengajarannya. Inovasi menejemen pengajaran bukan pada wujud fisik, melainkan juga yang nonfisik Suatu usaha mengantarkan praktik agar membawa perubahan sosial. Dalam praktik tidak memerlukan semua baru, semua potensi dan efesien dalam konteks baru merupakan kriteria utama menggunakan label atau symbol inovasi. Penekanannya kepada inovasi yang berhubungan dengan persoalan nasional, local dan spesifik. Dalam hal ini perencanaan program disekolah dilakukan dengan berbagai cara supaya pengajar menjadi inovatif dengan mengadakan banyak agenda pelatihan, worshop dari instansi pemerintah maupun pengembangan secara mandiri. Guru dalam melaksanakan kegiatan Proses Belajar Mengajar selalu berganti ganti metode sesuai dengan kondisi kelas yang diampunya. Banyaknya inovasi yang diciptakan seorang guru dalam Proses Belajar Mengajar menjadikan siswa senang dan sangat responsive, sehingga tercipta suasana belajar yang kondusif dan siswa menjadi lebih berprestasi dengan menunjukkan hasil belajar siswa.

\begin{tabular}{lll}
\multicolumn{2}{l}{ Tabel } & \multicolumn{2}{l}{ Data sarana dan prasaran sekolah } \\
\hline No & Jenis Sarana dan Prasarana & Jumlah \\
\hline $1 . \quad$ & Lahan & 1 \\
& Lahan Bangunan & 1 \\
& Lahan Lapangan Upacara & 1 \\
& Kebun & 1 \\
& Lahan Yang Dipagar & \\
2. & Ruang & 1 \\
& Ruang Belajar & 1 \\
& Ruang Kepala Sekolah & 1 \\
& Ruang Guru & 1 \\
& Ruang TU & 1 \\
& Ruang Perpustakaan & - \\
& Ruang Laboraturium & 1 \\
& Ruang Mushola & - \\
& Ruang Dapur dan Gudang & - \\
Ruang Administrasi & \\
3. Peralatan & - \\
Komputer & - \\
\hline
\end{tabular}

Perencanaan dengan memperhatikan kondisi dilapangan sangatlah penting di SMA IT Cendekia. Beberapa sarana dan prasarana meskipun masih terbatas misalnya tidak adanya sarana dan prasarana seperti ruang laboratorium (Tabel 1), tidak mengurangi kemampuan guru-guru SMA IT cendekia dalam melakukan inovasi pembelajaran untuk menutupi kekurangan tersebut. Hal ini terbukti dengan berhasilnya siswi SMA IT cendekia yang lolos dalam perlombaan karya ilmiah di Hongkong.

\section{Pengorganisasian (Organizing)}

Selanjutnya Inovasi pembelajaran diadakan untuk membantu guru dan siswa dalam menata dan mengorganisasi pembelajaran menuju tercapainya tujuan belajar. Untuk itu, dapat dirangkai bahwa ada tujuan yang menjadi akhir dari sebuah proses mengelola pembelajaran agar mencapai tujuan. Dalam kaitannya dengan pendidikan, ada tujuan-tujuan mendasar dari proses pendidikan. Oleh karena itu, jika disandingkan antara manajemen dan inovasi pembelajaran sangatlah erat kaitannya. Pendidikan dengan inovasi pembelajaran memiliki tujuan, sedangkan manajemen atau pengelolaan juga agar mencapai tujuan. Inovasi manajemen pembelajaran sangatlah perlu diterapkan dalam proses pembelajaran, tanpa manajemen yang tertata baik tentu akan sangat sulit untuk mencapai tujuan.

Dalam mengkoordinasikan sebuah lembaga pendidikan yang ada di SMA Islam Terpadu Samawa Cendekia, dengan civitas akademik yang meliputi yayasan, dinas pendidikan, kepala sekolah, wakil kepala sekolah, guru, karyawan, siswa dan komite sekolah serta orang tua 
wali. Yang selalu bersinergi dalam pelaksanaan pembelajaran disekolah. Pada waktu merencanakan program sekolah selalu mengadakan koordinasi untuk pelaksanaannya kegiatan program program disekolah.

\section{Pengorganisasian (Acting)}

Pelaksanaan Proses Belajar Mengajar di SMA Islam Terpadu Samawa Cendekia dalam menyelenggarakan Proses Belajar Mengajar tentunya sangat memperhatikan metode pembelajaran yang diterapkan sesuai dengan kurikulum yang berlaku dengan menyusun rencana pembelajaran yang merupakan kewajiban seorang guru sebelum melakukan aktivitas pembelajaran. Selanjutnya guru dituntut untuk mengembangkan diri dengan inovatif sehingga dapat tercipta suasana belajara yang kondusif dan berintelektual. Metode yang dilakukan guru dalam Proses Belajar Mengajar dengan model inovasi yang dimilikinya diharapkan mampu meningkatkan prestasi siswa. Selain itu, guru yang mampu menciptakan inovasi pengajaran juga merupakan prestasi baginya.

\section{Pengorganisasian (Acting)}

Pengawasan dilakukan oleh pengawas sekolah dan juga dibantu oleh komite dan kepala sekolah untuk mengawasi kegiatan Proses Belajar Mengajar maupun portofolio para guru. Karena didalam Proses Belajar Mengajar guru perlu berinovasi supaya tidak menimbulkan kejenuhan pada siswa. Dengan demikian Inovasi pengelolaan pendidikan dilakukan sedini mungkin maka lembaga pendidikan akan memiliki kualitas yang lebih baik daripada sebelumnya. Mutu layanan pendidikan akan dapat berjalan dengan prima, madrasah atau sekolah akan unggul, berprestasi, memuaskan, hasilnya bernilai tinggi, efektif, efisien, produktif, sehingga lulusan madrasah atau sekolah akan memiliki kompetensi sesuai yang diharapkan oleh semua pihak baik masyarakat, orang tua maupun madrasah bahkan bangsa dan agama saat ini.

\section{Pengawasan (Monitoring)}

Pengawasan dilakukan oleh pengawas sekolah dan juga dibantu oleh komite dan kepala sekolah untuk mengawasi kegiatan Proses Belajar Mengajar maupun portofolio para guru. Karena didalam Proses Belajar Mengajar guru perlu berinovasi supaya tidak menimbulkan kejenuhan pada siswa. Dengan demikian Inovasi pengelolaan pendidikan dilakukan sedini mungkin maka lembaga pendidikan akan memiliki kualitas yang lebih baik daripada sebelumnya. Mutu layanan pendidikan akan dapat berjalan dengan prima, madrasah atau sekolah akan unggul, berprestasi, memuaskan, hasilnya bernilai tinggi, efektif, efisien, produktif, sehingga lulusan madrasah atau sekolah akan memiliki kompetensi sesuai yang diharapkan oleh semua pihak baik masyarakat, orang tua maupun madrasah bahkan bangsa dan agama saat ini.

\section{Prestasi Belajar Siswa}

Prestasi belajar siswa SMA IT samawa Cendekia setelah dilaksanakan inovasi manajemen pengajaran mengalami peningkatan. Hal tersebut terlihat dari tingkat ketuntasan belajar siswa yang semakin meningkat seperti yang tertera pada tabel 2 dibawah ini :

Tabel 2. Tabel ketuntasan belajar siswa SMA IT

\begin{tabular}{|c|c|c|c|}
\hline $\begin{array}{l}\text { Rentang } \\
\text { Nilai }\end{array}$ & Frekuensi & Perentase & Keterangan \\
\hline $\begin{array}{l}>70 \\
<70\end{array}$ & $\begin{array}{l}20 \\
2\end{array}$ & $\begin{array}{l}90,9 \\
9,1\end{array}$ & $\begin{array}{l}\text { Tuntas } \\
\text { Belum } \\
\text { Tuntas }\end{array}$ \\
\hline & 12 & 100 & \\
\hline
\end{tabular}

Peningkatan ketuntasan belajar siswa tersebut merupakan implikasi dari adanya manajemen inovasi yang baik dari seluruh perangkat sekolah. Mulai dari guru, kepala sekolah hingga orang tua siswa untuk menciptakan proses belajar mengajar yang lebih baik dari sebelumnya. Perubahan-perubahan kecil seperti cara guru dalam menyampaikan materi, metode pembelajaran yang disesuaikan dengan kondisi kelas dan lebih kreatif menjadi salah satu kunci keberhasilan selain daya dukung lainnya. Daya dukung lainnya antara lain perencanaan yang baik pengorganisasian hinggan evaluasi dan pengawasan.

\section{PENUTUP}

\section{Kesimpulan}

Berdasarkan kasil dan pembahasan yang telah dijabarkan pada poin sebelumnya, dapat diambil kesimpulan bahwa inovasi manejemen pengajaran dalam peningkatan prestasi siswa kelas $\mathrm{X}$ di SMA IT Samawa Cendekia Kabupaten Sumbawa tahun 2020. Dalam kegiatannya dengan menggunakan fungsi -fungsi manajemen yaitu perencanaan, pengorganisasian, pelaksanaan, dan pengawasan sudah terlaksa dengan sangat baik. Peran-peran guru terlihat dari proses perencanaan hingga pelaksanaan, guru melakukan berbagai macam inovasi pembelajaran terhadap peningkatan prestasi siswa. Beberapa sarana dan prasarana yang masih kurang dapat tertutupi dengan adanya inovasi pembelajaran dari guru. Fungsi pengawasan pun berjalan dengan sangat baik dan dilakukan secara berkala di SMA IT Samawa Cendekia.

Hasil inovasi manajemen pengajaran terlihat dari hasil belajar siswa yang meningkat sebelum dan setelah dilaksanakan inovasi pengajaran. Bentuk inovasi manajemen dalam 
pengajaran yang dilakukan guru berupa modelmodel pembelajaran yang kreatif seperti permainan teka-teki silang, tayangan video animasi yang berisi materi pembelajaran sehingga siswa lebih responsive dan cepat dalam memahami materi pembelajaran yang ada.

Adapun hal-hal yang perlu diperhatikan oleh guru adalah guru harus lebih siap dan memahami setiap kondisi proses pembelajaran yang terjadi di kelas, karena untuk melakukan inovasi yang tepat perlu disesuaikan dengan kondisi kelas atau proses belajar yang terjadi. Selain hal tersebut peran pengawasan harus selalu rutin dan berkala dilaksanakan agar mutu atau kualitas pembelajaran tetap terjaga dan ide-ide dalam melakukan inovasiinovasi selalu tercipta baik dari guru maupun perangkat sekolah lainnya.

\section{REFERENSI}

A. Pribadi, Benny. 2009. Model Desain Sistem Pembelajaran. Jakarta: PT Dian Rakyat.

A. Tabrani Rusyan, Drs., dkk. 1994, Pendekatan dalam Proses Belajar Mengajar, Bandung: Remaja Rosdakarya.

A.M., Sardiman. 2001. Interaksi dan Motivasi Belajar Mengajar. Jakarta: Raja Grafindo Persada

Aan Komariyah dan Djam'an satori, Metodologi Penelitian Kualitatif (Bandung: Alfabeta,2012)

Adi, Drs Dwi. 2001. Kamus Praktis Bahasa Indonesia. Surabaya: Fajar Mulya.

Djamarah, Syaiful Bahri. 2000. Strategi Belajar Mengajar. Jakarta: Rineksa Cipta.

J. Moleong, Lexy. 2000. Metode Penelitian Kualitatif. Remaja Rosdakarya; Bandung. $167 \mathrm{hlm}$.

Lilian, Vin. 2018. “Inovasi Manajemen Pembelajaran Sejarah (Studi Deskriptif Kualitatif di SMA Negeri 1 Ujan Mas)”. Tesis. Fakultas Keguruan Ilmu Pendidikan. Program Studi Magister Administrasi Pendidikan. Universitas Bengkulu. Bengkulu
Miles, M.B. \& Huberman, A.M. 1994. Qualitative Data Analysis. London: Sage Publishers.

Muhibbin Syah.2010. Psikologi Pendidikan dengan pendekatan baru.Bandung:PT Remaja Rosdakarya

Nasrun Harahap. 1994. Penilaian Hasil Belajar. Surabaya: Usaha Nasional

Nasution. 1992.Metode Penelitian Naturalistik Kualitatif, Penerbit Tarsito, Bandung.

Nurchasanah, Iin. 2018. "Manajemen Pengembangan Profesionalisme Guru dalam Meningkatkan Kualitas Pembelajaransiswa di Mtsn Kepoh Delanggu Klatentahun Ajaran 2017/2018”. Tesis. Program Studi Manajemen Pendidikan Islam Pascasarjana. Institut Agama Islam Negeri Surakarta. Surakarta

Santi. 2018. "Pengembangan kompetensi guru dalam peningkatan prestasi belajar siswa di SMP Al Mubarok PondokAren”. Tesis. Fakultas Ilmu Tarbiyah dan Keguruan Universitas Islam Negeri Syarif Hidayatullah

Slameto. 2003. Belajar dan Faktor-faktor yang Mempengaruhinya. Jakarta: Rineka Cipta.

Sumadi Suryabrata, 1998. Psikologi Pendidikan. Jakarta: PT. Raja Grafindo Persada.Agama Islam Negeri Surakarta.

Suryanto. 2017. "Inovasi manajemen pengajaran dalam peningkatan prestasi belajar siswa kelas 2 Madrasah Ibtidaiyah Muhammadiyah (MIM) Sabranglor Trucuk Kabupaten Klaten tahun 2016”. Tesis. Program Studi Manajemen Pendidikan Islam Pascasarjana

Undang-undang nomor 19 tahun 2002 tentang Hak Cipta.

Uno, Hamzah B. 2007. Teori Motivasi dan Pengukurannya (Analisis di Bidang Pendidikan). Jakarta: Bumi Aksara

Uno, Hamzah B. 2010. Perencanaan Pembelajaran. Jakarta: Bumi Aksara

WS. Winkel. 1996. Psikologi Pendidikan dan Evaluasi Belajar. Jakarta: PT Gramedia 